\title{
柱消失後の骨組構造物の鉛直終局挙動と潜在的耐荷機構 ULTIMATE BEHAVIOR AND POTENTIAL RESISTANT MECHANISM OF FRAMED STRUCTURES AFTER MEMBER DISAPPEARANCE SUBJECTED TO VERTICAL LOAD
}

伊藤拓海*，福山達也**

Takumi ITO and Tatsuya FUKUYAMA

\begin{abstract}
Even if one or a set of structural member in building structures disappears suddenly due to accidental loads, the building should stand against vertical gravity loads, dead or live. This study investigates the structural redundancy and the effects of catenary action based on another resistant mechanism after failure mechanism formation. In this paper, the ultimate resistant mechanism of framed structures is investigated experimentally and analytically. The static loading tests have been conducted. From the comparison with analytical results, the non-linear push-down analysis shows good agreements with test result. Furthermore, the limit analysis based on the upper boundary theory is proposed.
\end{abstract}

Keywords : Framed structure, Redundancy, Static vertical loading test, Push down analysis, Limit analysis 骨組, 穴長性, 静的鉛直載荷実験, 弾塑性増分解析, 極限解析

\section{1. はじめに}

近年，予想外の外乱や偶発的荷重により，構造物は柱・梁などの 構造躯体が甚大な被害を受け, 荷重伝達経路が消失し, その結果と して建物が倒壊するという被害例が世界中で散見されている。一方 で，過去の建築構造物の地震被害例などに見るように，構造躯体や 接合部の破断, 座屈といった終局状態に達しても, 構造物のフェイ ルセーフ機構により倒壊を免れた例 ${ }^{1)}$ や，2001 年世界貿易センター ビルの同時多発テロでは, 旅客機が衝突して最終的には完全崩壊に 至ったが，構造躯体消失という最贯の事態に至り，かつ火災による 高温化の過酷な状況下で数時間建ち続けたという見方もある ${ }^{2)}$. 建 築構造物は不静定次数が高く, 材料や部材の構造性能に関するばら つきを考慮して高い安全率が見積もられている。ささらに, 構造部材 の優れた勒性や変形能力を利用した塑性設計法が普及し, 構造物の 変形能力を高めてそれを利用した設計が行われているため，上記の ような部材の消失や破断といった過酷な状況が，すぐに倒壊に結び つかないケースが散見されている。これらの圥長性は, 構造物の潜 在的な性能の一つであるが，顕在化させて積極的に評価し，設計に 取り組むことが検討されている ${ }^{3)}$.

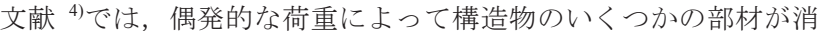
した場合に, 固定的積載荷重によって構造物が全体崩壊するか否か を, 構造物耐荷力の急激な減少を表す感度分析によって検討した. 同文献で定義された部材感度（Sensitivity Index）は，Frangopol らの
提案した午長性指標 ${ }^{5)}$ の逆数に相当するものであり，構造物耐荷力 に対する部材の影響度や支配度を表したものである。この他にも， Feng らは, 骨組のある部材が消失した場合の骨組耐力と, 元の状態 の骨組耐力の比を, 壳長性に関わる指標として定義している ${ }^{6)}$. Schafer らは, Feng らの定義に基づいて, 部材消失前後における座 屈荷重係数の減少量を対象として, 圥長性に関わる検討を行ってい る ${ }^{7)}$. Paliou らは, 複数の部材が同時に損傷する事象のもとで, 構 造物が崩壊しないための条件付確率を圥長性の指標として定義して いる ${ }^{8}$.

以上の冗長性に関わる指標は，図 1 に示すように，健全な状態に おける骨組の耐力 $\lambda_{0} P_{0}$ と，部材が甚大な損傷を被った状態の骨組 の耐力 $\lambda_{d} P_{0}$ との比較によって議論されている.

例えば，文献 ${ }^{4)}$ の方法のように，微小変形理論に基づく塑性解析 は，変形前の構造物の耐荷力と崩壊メカニズムを求めることができ る。一方，鉛直荷重を受ける弾塑性構造物の静的な大変形解析を行 うと，崩壊メカニズム形成後も荷重が増加することがある（図 1). これは，崩壊メカニズム形成前の釣合では考慮していない別の耐荷

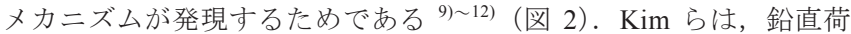
重を受ける骨組において，梁軸力の鉛直分力の効果（カテナリー効 果）に注目し，進行性崩壊の検討を行っている ${ }^{13)}$.

本研究では, 塑性解析から求まる崩壊機構形成後に, 節点の移動 によって別の耐荷機構が現れた場合，その機構に基づく耐力増分と
* 東京理科大学工学部第一部建築学科 講師 ·博士 (工学)

** 東京理科大学大学院工学研究科建築学専攻 大学院生·学士 (工学
Lecturer, Dept. of Architecture, Faculty of Engineering, Tokyo University of Science, Dr. Eng. Graduate Student, Dept. of Architecture, Graduate School of Engineering, Tokyo University of Science, B. Eng. 
圥長性に関わる検討を行うことを目的としている.

部材消失後に, 固定的鉛直荷重が塑性崩壊荷重を上回る場合, 骨 組は塑性崩壊する。これに対して, 上述の塑性崩壊後の耐荷機構に よる耐力増分に期待することができる場合，このような崩壊を回避 できる可能性がある. 一方, 塑性崩壊後の耐荷機構を考慮しても, 耐力増分が期待できない骨組においては即座に崩壊に至る. 寸なわ ち, 塑性崩壊後の耐荷機構による耐力増分の大きさにより, 脆性的 な終局状態を迎える骨組と, 圥長性のある挙動を示す骨組が存在す ることが考えられる.

実際の建築構造物では, 終局状態において部材の座屈, 破断が生 じる.さらに, 接合部においても, 接合要素（ボルト，溶接継目な ど）の破断などが生じる. これに対して, 本研究では, 図 1,2 に示 すように, 骨組力学としての終局耐荷機構に焦点をあて, 塑性崩壊 後から終局状態に至るまでの耐荷機構の推移に着目している. その ため, 実際の建築構造物においては, 上記の座屈や破断に起因した 変形制限があるが, 仮にこれらの限界状態を無視した場合, 終局耐 荷機構により耐力増分がどの程度得られるかに着目している。 つま り, 本実験により, 図 1 に示寸ように, 終局状態に至るまでの潜在 的な骨格曲線を得ることを主たる目的としている.

本稿では, 骨組の終局耐荷機構に着目して, 図 1 に示すような脆 性的な終局状態を回避するために, 骨組が具備しておくべき条件に
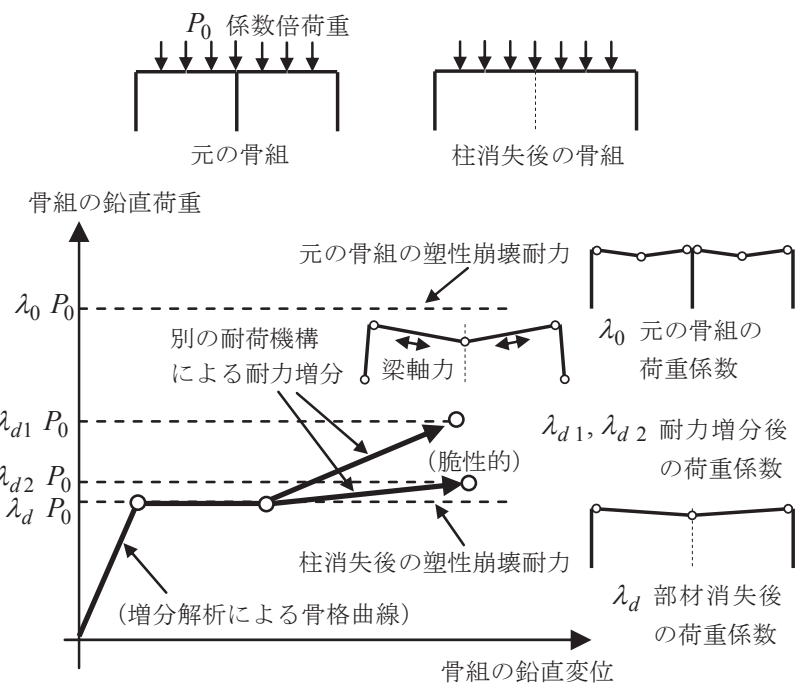

図 1 部材消失後骨組の荷重変形関係

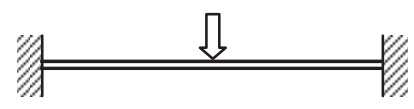

集中荷重を受ける両端固定梁

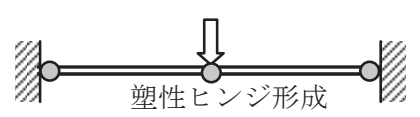

1 次の塑性解析

(釣合式と塑性条件のみ)

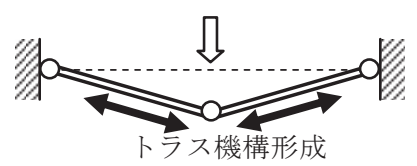

2 次効果を考慮した塑性解析

（節点移動による変形を考慮）

図 2 塑性崩壊後の節点移動を考慮した耐荷機構 ${ }^{9}$
ついて検討し，咒長性に優れた骨組の実現に向けた検討を行うこと を目的としている.

\section{2. 柱消失後骨組の静的鉛直載荷実験}

\section{1 実験概要}

本研究では，部材消失後の骨組において，鉛直荷重に対する終局 挙動について実証的な検討を行うことを目的とした実験を行った.

ここでは, 柱消失後の骨組を想定し, 図 3 に示寸ように 1 層ならび に 2 層規模の 2 スパンラーメン骨組の試験体模型を製作し，静的鉛 直載荷実験を実施した。

\section{2 試験体と使用鋼材の機械的性質}

試験模型は，鋼板（SS400, t=32mm）より切り出して柱ならびに 梁部材を製作し，柱梁接合部は図 3 に示すように完全溶込み溶接に よって製作した，部材断面については，柱が $32 \mathrm{~mm} \times 60 \mathrm{~mm}$ ，梁が $32 \mathrm{~mm} \times 30 \mathrm{~mm}$ とした. 試験体の使用鋼材の機械的性質を表 1 に示寸. また，柱と梁の塑性耐力を表 2 に示寸.

\section{3 載荷方法}

図 4 に示すように, 万能試験機により圧縮載荷実験を行った。試
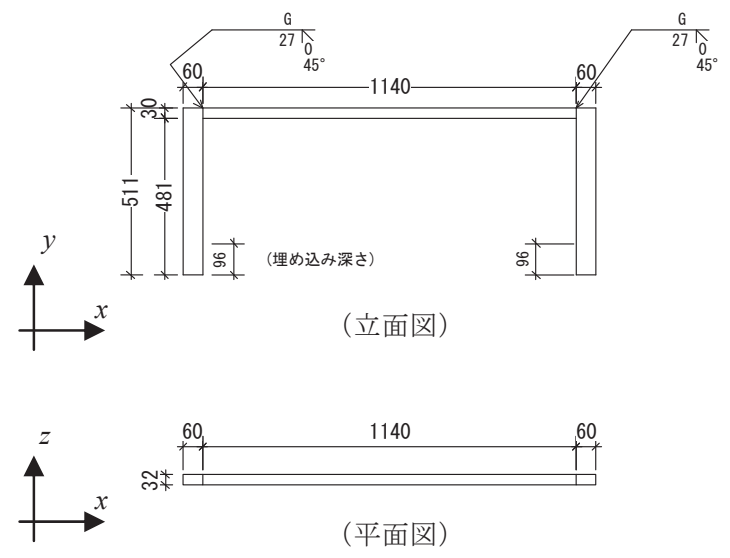

(a) 1 層骨組の試験体（単位 : mm）

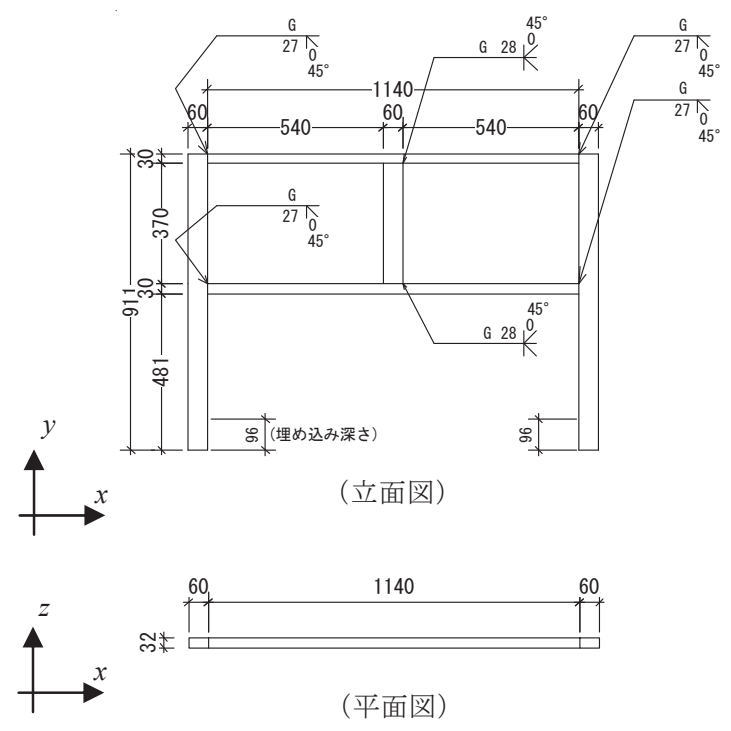

(b) 2 層骨組の試験体（単位 : $\mathrm{mm}$ )

図 3 試験体の構成と寸法 
験機のクロスヘッドにナイフエッジを設置し, 試験体中央部に集中 鉛直荷重を与えた. 図 4 に示すように, 試験体の柱脚部を板厚 $32 \mathrm{~mm}$ の鋼材を 3 枚重ねたもので挟み込み，高力ボルトで固定した.

実験は，1 層試験体についてはナイフエッジの台座が試験体の梁 に接触する直前まで加力を行った。また, 2 層試験体については, 試験機の変位制御限界まで加力を行った。その結果として, 1 層試 験体においては柱脚が曲げ降伏するまで載荷することができたが, 2 層試験体において柱脚は弾性範囲であった。

\section{4 計測計画}

計測について，荷重は試験機のロードセルより検出した。荷重点 の鉛直変位は，棒状変位計によって計測した，各階床位置における 水平変位は, 図 5 のようにレーザー変位計によって計測した. また, 図 5 に示寸位置に貼付したひずみゲージより断面の最外縁ひずみを 求め, 平面保持を仮定して断面のひずみ分布を求め, さらに材料試 験結果の応力ひずみ曲線より断面の応力分布を求めた. 得られた応 力分布より, 試験体の曲げモーメントならびに軸力を求めた.

\section{5 実験結果}

実験結果において, 鉛直荷重一梁の部材角関係を図 6 , 梁軸力と

表 1 使用鋼材の機械的性質

\begin{tabular}{|l|l|l|l|}
\hline 降伏強さ & 引張強さ & 破断伸び & ヤング係数 \\
\hline $241 \mathrm{~N} / \mathrm{mm}^{2}$ & $406 \mathrm{~N} / \mathrm{mm}^{2}$ & $35 \%$ & $203 \mathrm{GPa}$ \\
\hline
\end{tabular}

\begin{tabular}{|c|c|c|}
\hline 部位 & 曲げ耐力 & 降伏軸力 \\
\hline 柱 & $6.77 \mathrm{kNm}$ & $451 \mathrm{kN}$ \\
\hline 梁 & $1.69 \mathrm{kNm}$ & $225 \mathrm{kN}$ \\
\hline
\end{tabular}

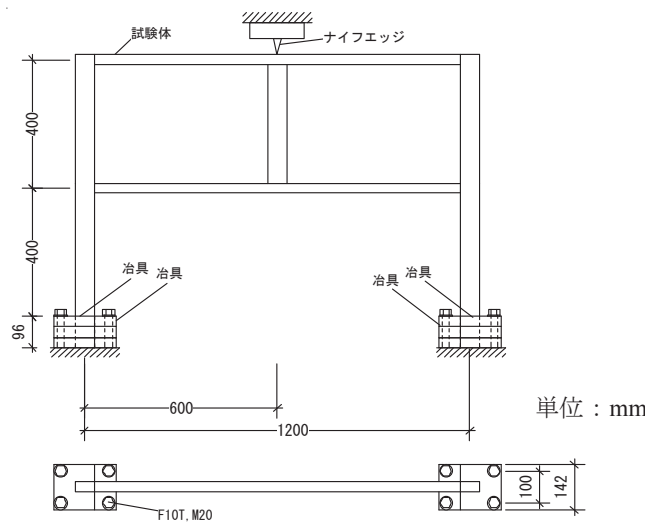

図 4 試験体のセットアップ（2 層骨組の場合）

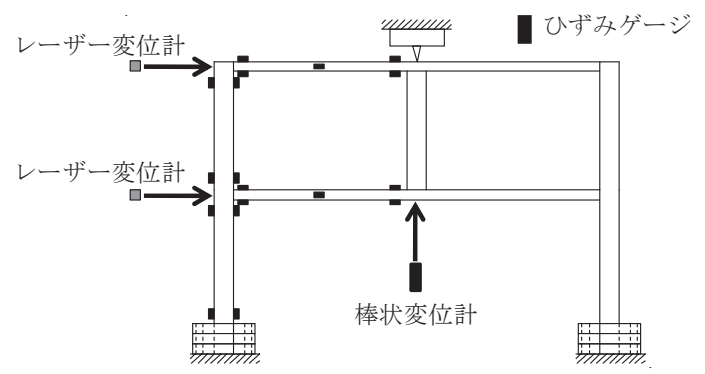

図 5 計測図（2 層骨組の場合）
梁の部材角との関係を図 7, 鉛直荷重と柱の水平部材角との関係を 図 8, 柱頭と柱脚のモーメントと梁の部材角との関係を図 9 にそれ ぞれ示す，なお，モーメントは，柱は骨組の内側が引張となる向き を正とし，梁は下側が引張となる向きを正とする．軸力は，引張を 正とする.

耐荷機構の推移を示すため, 弾性範囲（(A)点）, 梁端の塑性ヒン ジによる塑性崩壊機構形成時（(B)点）を図 10 に示す。また，終局 状態として，1 層骨組の場合は柱脚が降伏モーメントに達した時点， 2 層骨組の場合は載荷を終了した時点（(C)点）の応力図と変形図を 図 10 に示している。2.4 節の方法によりひずみゲージからモーメン

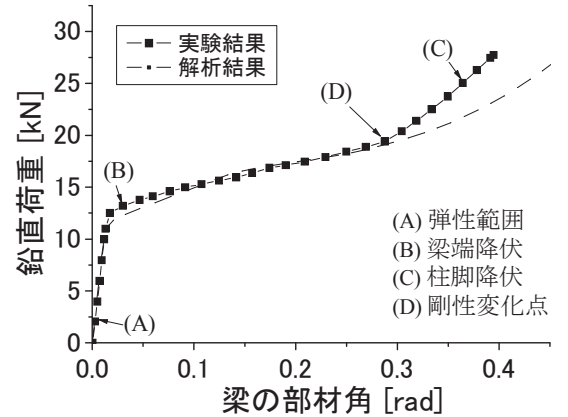

(a) 1 層骨組

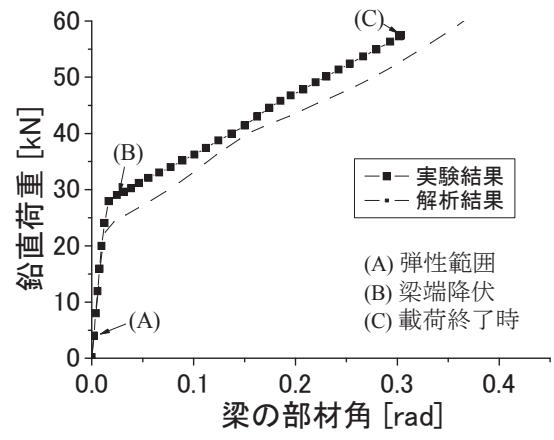

(b) 2 層骨組

図 6 鋁直荷重一梁の部材角関係
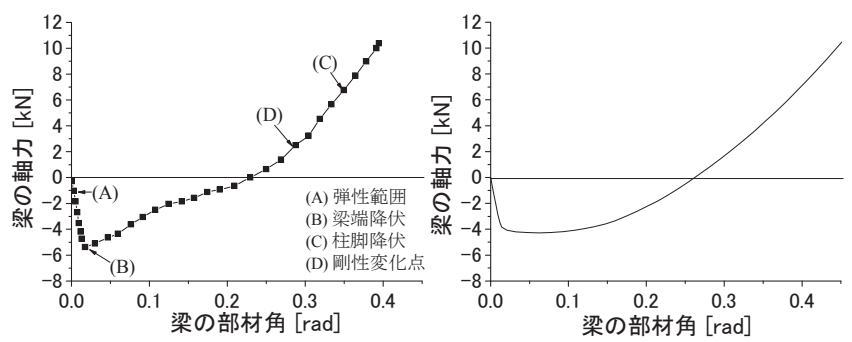

(a) 1 層骨組
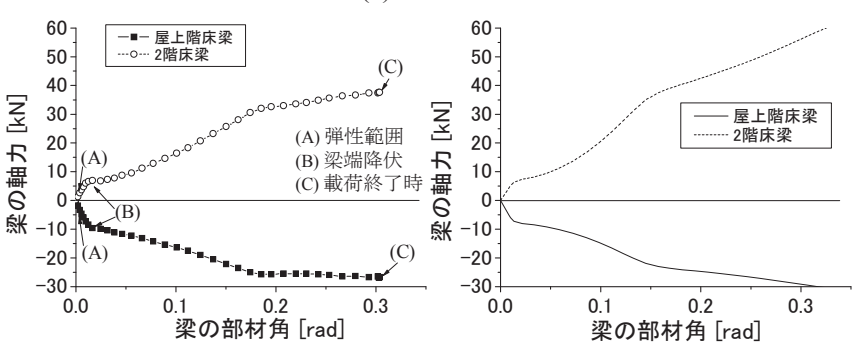

(b) 2 層骨組

図 7 梁軸力一梁の部材角関係（左：実験，右：増分解析） 
卜と軸力を求め, 図 10 に合わせて示している. なお, ひずみゲージ が剥がれて曲げモーメントを求めることができなかった場合につい ては, 節点まわりのモーメントの釣合いより求め, 同図の破線で示 している. さらに, 1 層骨組の荷重変位関係や梁軸力一梁部材角関 係の結果において，その勾配が大きくなった点を(D)点とする。これ らの各時点における実験結果を図 6〜9に合わせて示す. また, 実験 終了後の試験体の様子を図 11 に示す.

図 6 の結果より, (B)点において梁端の塑性ヒンジ形成による塑性 崩壊後，ひずみ硬化によって荷重が増分するが，その後剛性が大き くなって荷重が増加する様子が確認できる.この第 3 勾配に関して, 1 層骨組の試験体においては, 図 7 (a)の(D)点以降で梁軸力と梁部材 角関係の勾配が増加するが，この時点と対応している.さらに,
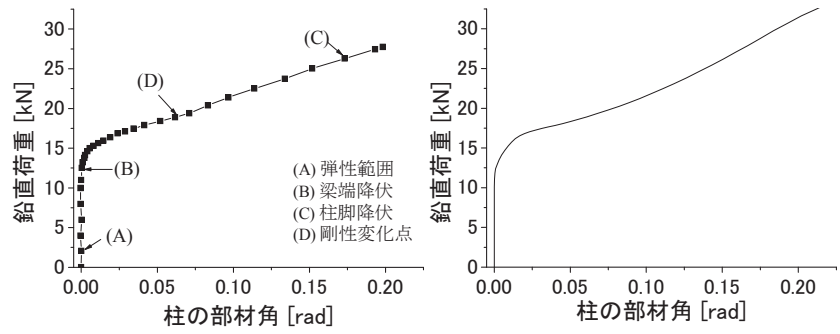

(a) 1 層骨組
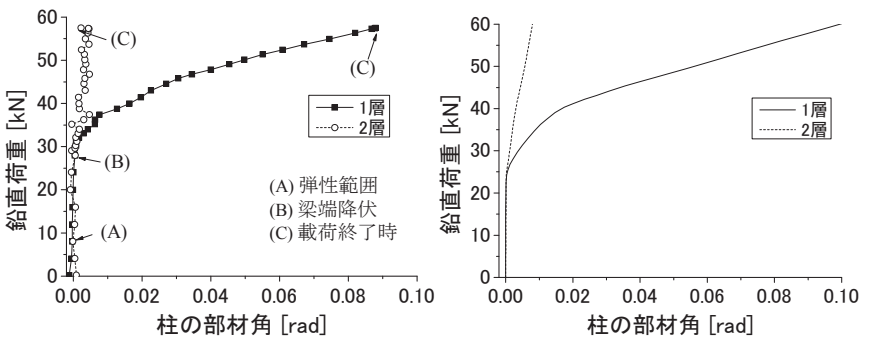

(b) 2 層骨組

図 8 鉛直荷重一柱の水平部材角関係

（左：実験，右：増分解析）
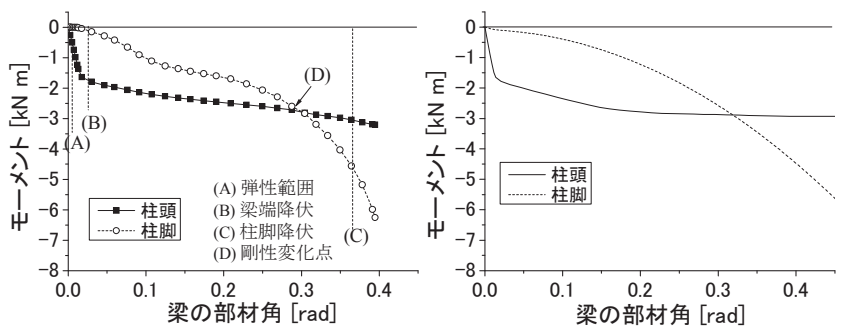

(a) 1 層骨組
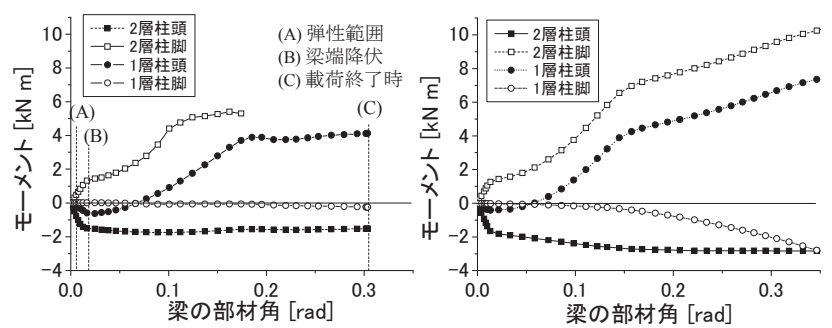

(b) 2 層骨組

図 9 柱頭・柱脚モーメントー梁の部材角関係 (左 : 実験，右：増分解析)
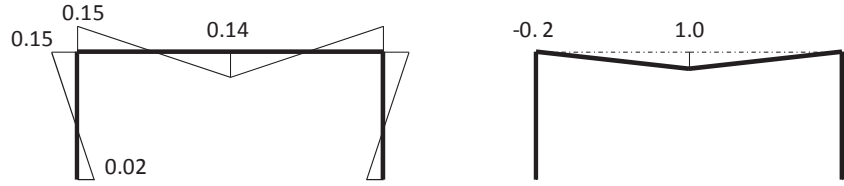

梁軸力 : -0.56

(A) 弾性範囲
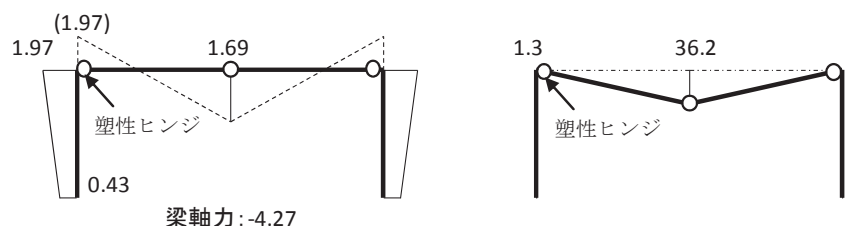

(B) 梁の曲げ崩壊時
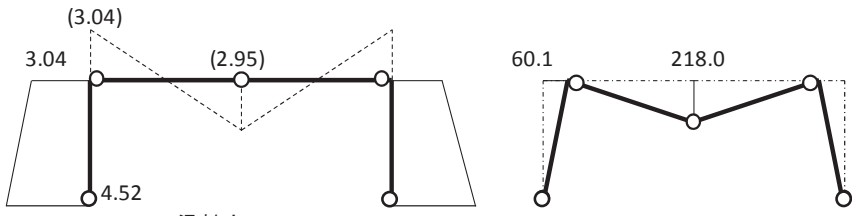

(C) 載荷終了時 (柱脚降伏時)

(a) 1 層骨組
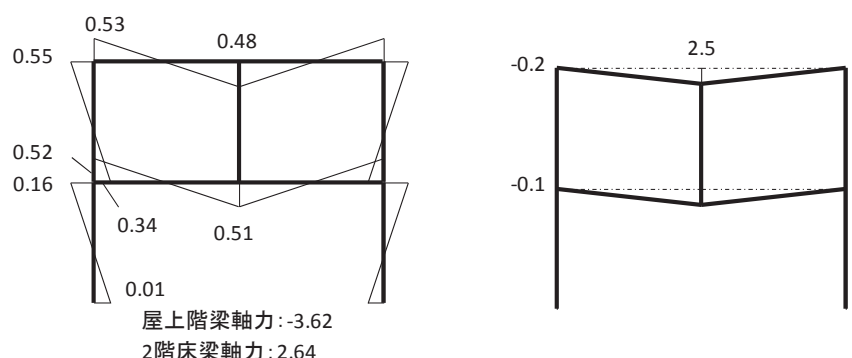

(A) 弾性範囲
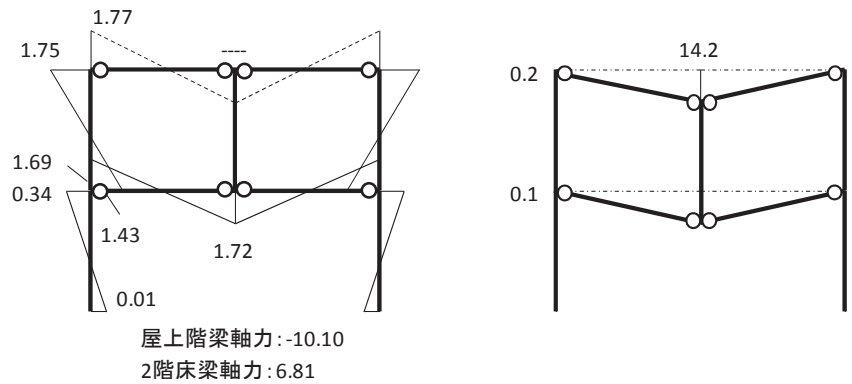

(B) 梁の曲げ崩壊時
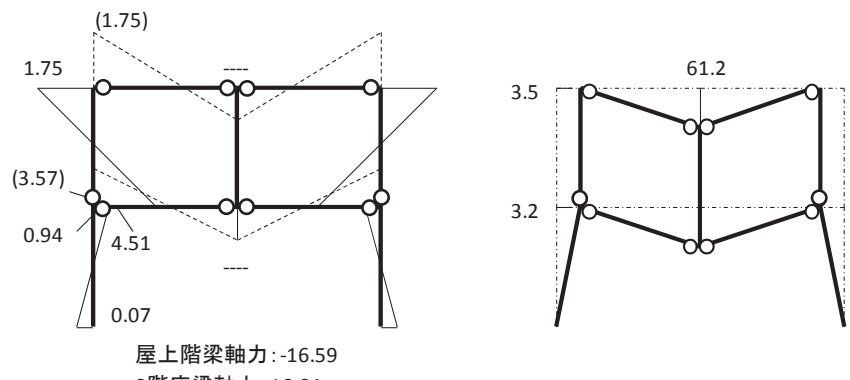

階庆梁軸力: 16.64

(C) 載荷終了時

(b) 2 層骨組

図 10 実験結果における応力図と変形図の推移

(単位：モーメント $[\mathrm{kN} \mathrm{m}]$, 軸力 $[\mathrm{kN}]$ (左図), 変位 $[\mathrm{mm}]$ (右図)) 
図 9 (a)の(D)点以降で柱脚モーメントが増加する時点と対応してい ることが確認できる.

また, 図 8 の結果より, 荷重変位曲線上の 2 次勾配において柱の 水平変位が急激に増加している様子が確認できる. さらに, 2 層骨 組の試験体においては， 2 層部の層間変形が 1 層に比べて非常に小 さく, 水平変形していない様子が確認できる. これは, 図 11 の載荷 後の試験体写真と対応していることが確認できる.

以上の崩壊プロセスならびに耐荷機構の推移は, 第 2 勾配におい ては塑性ヒンジ部の梁のひずみ硬化による荷重増分であるが，その 後, 荷重点の鋁直変位が増加して梁軸力が増加し, 柱の水平耐力に よって荷重点の鉛直分力が増加している.

\section{3. 鉛直静的弾塑性増分解析と耐荷機構の推移}

\section{1 鉛直静的弾塑性増分解析による解析的検討}

図 3 の骨組に対して, 弾塑性ジョイントモデル（柱梁端）による 静的弾塑性解析プログラム注 1)を用いて荷重増分解析を行う ${ }^{14) \sim 16)}$.

これにより，実験では求めることができなかった耐荷機構の推移に 関して，解析的な検討を行うことを目的としている。

\section{2 鉛直静的弾塑性増分解析の概要}

同プログラム注 ${ }^{1)}$ の手法は，以下の解析仮定をしている（図 12）.

1) 柱・梁部材を弾性要素と複数の履歴バネからなる弾塑性ジョイン 卜部分で置換する

2) 弾塑性ジョイントは塑性ヒンジが生じやすいところに置く

3) 弾塑性要素は有限の長さを持つ

4) 弾塑性要素における短軸履歴バネによって部材の軸力・2 軸曲げ の弾塑性挙動を表現する. これにより, 軸力一曲げの耐力相関が自 動的に考慮される

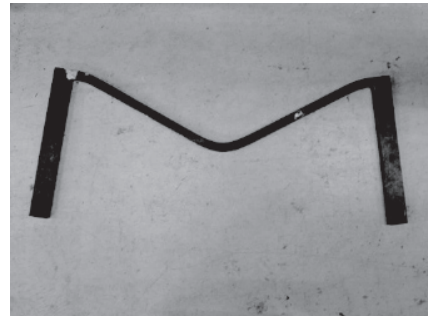

(a) 1 層骨組

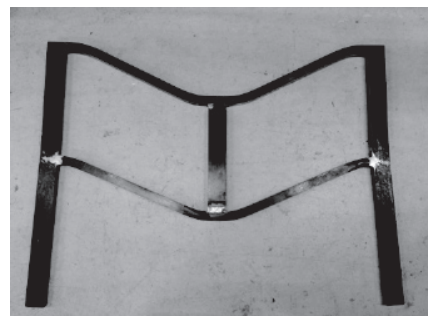

(b) 2 層骨組
図 11 実験終了後の試験体の様子

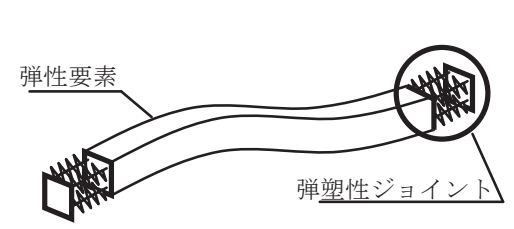

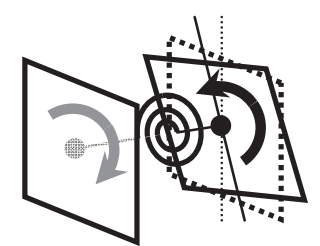

ねじりバネ要素（弾性）

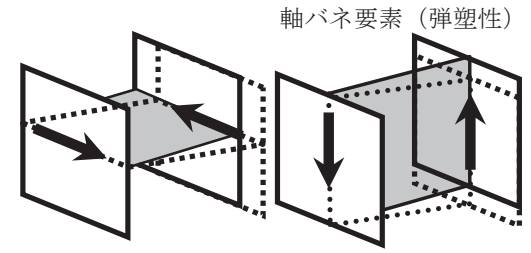

せん断バネ要素（弾性）
図 12 弾塑性ジョイント要素の成分注 1$)$
5) せん断, ねじりモーメントに対する要素は, せん断バネ, ねじり 回転バネによってそれぞれ独立にモデル化する

6) 弾性要素については通常の弾性はり要素を用いる

7) 材料の非線形性は, 弾塑性要素の両端面を結ぶ複数の軸バネの復 元力一変位関係から得られる履歴特性の形で与える

8) 節点移動による鉛直荷重の影響, 寸なわち $P$ - $\Delta$ 効果を考慮する 3.3 解析モデルと条件

本稿では, 平面骨組を対象として 2 次元の弾塑性増分解析を行う. ここで，実験結果の終局状態において，梁軸力の水平分力により柱 脚部モーメントが増加する際, 柱脚部の固定冶具に変形が確認され た。そこで，図 13 に示すように，解析モデルは柱脚部を回転バネで モデル化し，柱・梁の部材端には弾塑性ジョイントを設けて，平面 モデルによってモデル化する，なお，柱脚バネは弾性範囲とし，実 験結果と一致するように回転バネ剛性を調整した。1 層骨組の場合 については, 図 6 (a)に示すように(D)点まで実験結果と一致するよ うに回転バネの剛性を調整した。

弾塑性ジョイント部における各短軸履歴バネの復元力特性は, 材 料試験結果の応力ひずみ曲線に基づいて Tri-linear 型でモデル化す る. 弾塑性ジョイント部の断面は, 図 14 に示すように 10 本の弾塑 性ジョイントバネで近似した. 各短軸履歴バネの耐力は, 図 14 で示 される各バネの支配面積に材料試験結果の応力度を乗じて求めた. また，軸剛性は軸バネの長さ $20 \mathrm{~mm} （$ 柱部材長さの $5 \%$, 梁部材長さ 3.3\%）として求めた. ここで弾塑性ジョイントの長さに関して, 部 材の塑性化領域の広がりやその長さに応じて決定する方法も考えら

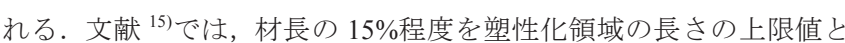
し，また弾塑性ジョイントが長くなると部材耐力や部材全体の弾性 変形にも誤差を生じることなどを勘案し，材長の $10 \%$ としている.

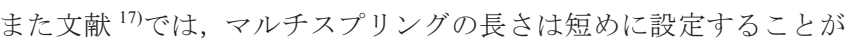
四弾塑性ジョイント
○) 弾性回転バネ
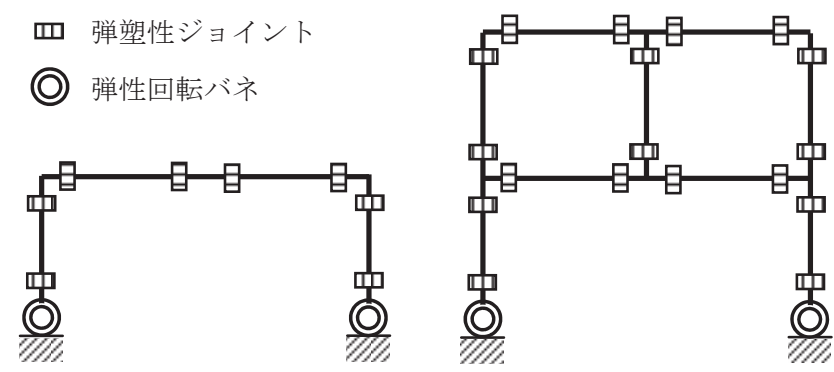

図 13 解析モデル
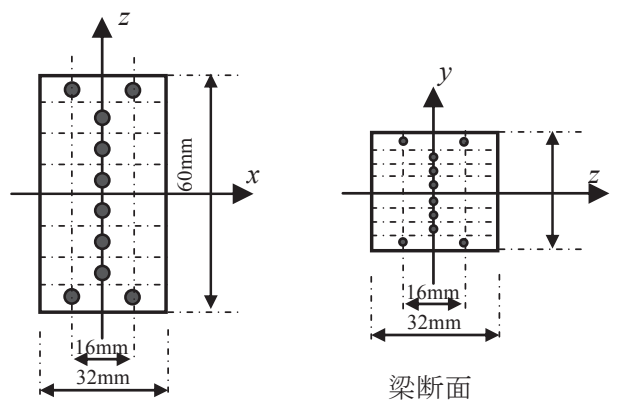

柱断面

図 14 弾塑性ジョイント部の断面のモデル化 
好ましいが，短すぎると収束安定性が悪くなることが指摘されてい

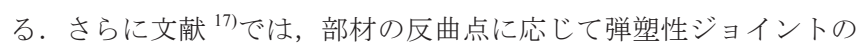
必要長さを導いている. 本稿では, これらの条件を勘案して上記の 長さを設定した. なお, ジョイント長さを変化させて解析を行った が, 終局耐力や耐荷機構の推移に有意差がないことを確認しており, 本稿では上記の条件の解析結果を示している.

弾塑性増分解析過程において, 曲げ系から軸力系へ移行する際, 曲げによる圧縮が引張に転じることがある。そこで，軸バネに対し てスケルトン・シフト・モデル ${ }^{14)}$, 18) と呼ばれる履歴則を適用する. このモデルは, 予め正側負側に設定したスケルトンを, それぞれ逆 方向のスケルトン上で過去に経験した塑性変形に比例させてシフト させる. またスケルトンから除荷が起こり, 逆側のスケルトンに到 達するまでの除荷曲線に対して, 図 15 のように Ramberg-Osgood モ デルで用いられる連続的な関数でモデル化する.この履歴則は, 紡 錘型の履歴曲線を示す部材の復元力特性モデルとして採用されてい るが，スケルトンをシフトさせる際の比例常数（シフト係数） $\psi$ を 調整することにより, 様々な履歴モデルを表現することができる. 例えば， $\psi=1$ とすると軟化部分を考慮しない加藤・秋山モデル ${ }^{19)}$ に一致し, $\psi=2$ として軟化部分の関数式を線形ないし区分線形に 変更すると単軸等方硬化モデル， $\psi=0$ としてノーマル・バイリニ ア・モデルや進行スリップ・モデルなども表現することができる. 軟鋼の繰返し載荷実験結果に適用した例では, シフト係数 $\psi=0.65$ $\sim 0.85$, 丸夕係数 $r=5$ を用いて実挙動を再現している ${ }^{15), 16)}$. また, 極低降伏点鋼を用いた履歴型ダンパーの復元力特性に適用した例で は, 丸み係数 8 , シフト係数 $\psi=0.9^{18)}, \psi=0.97^{20)}, \psi=0.65^{21)}$ が採用 されている.さらに文献 ${ }^{15}$ では, シフト係数は軟鋼の実験結果との 適合度に大きな影響を与えるが，丸み係数の選択については，ある 範囲で変動しても影響が大きくないことを示している．以上より， 本稿ではシフト係数 $\psi=0.5$, 丸夕係数 5 とした. なお, シフト係数 0.4 0.9, 丸み係数 1,5 とした場合の解析を行ったが, 終局耐力や 耐荷機構に有意差がないことを確認している.

\section{4 実験結果と解析結果の比較と考察}

弾塑性増分解析結果において, 鉛直荷重一梁の部材角関係を図 6, 梁軸力と梁の部材角との関係を図 7, 鉛直荷重と柱の水平部材角と の関係を図 8 , 柱頭と柱脚のモーメントと梁の部材角との関係を図 9 に, 実験結果と比較して示す.

図 6 の結果より, 弾塑性増分解析は, (D)点まで実験結果の荷重変 位関係を追跡できていることが確認できる. 図 7 の結果より, 梁端

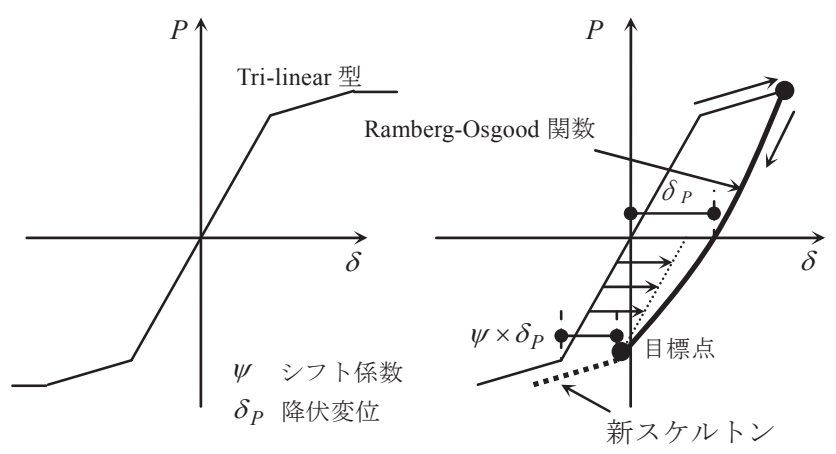

図 15 除荷時曲線のモデル ${ }^{14), 18}$
降伏による崩壊モード形成後, 梁軸力が増加する傾向を追跡できて いる. 図 8 の結果より，2 層骨組の場合は 1 層の柱の水平変位が増 加し, 実験結果と同様の崩壊機構によって終局状態を迎えている様 子が確認できる．図 9 の結果より，曲げ応力分布は実験結果と同様 の傾向を示していることが確認できる.

ここで，図 6 (a)に示す 1 層骨組の鉛直荷重一梁の部材角関係の結 果において, (D)点以降, 弾塑性増分解析は実験結果と比較して変形 が大きくなっている，同図の結果では，(D)点までを追跡できるよう に柱脚回転バネを調整したが，これに対して回転剛性を大きくする と柱の水平変位が小さくなり，梁の部材角が小さくなる，また，回 転剛性を小さく寸ると梁の部材角が大きくなる．以上の検討結果よ り，柱脚回転バネを調整することで終局状態における骨組の変位が 異なり, (D)点以降も荷重変位関係を追跡できることを確認している. ただし, 塑性崩壊後の耐荷機構の推移や応力図の傾向に大差はなく, 本解析手法によって終局状態と終局耐力を精度よく追跡できると考 えられる。

2 層骨組の実験では, 試験機の変位制御限界に達したため, 試験 体の終局状態まで加力することができなかった。これに対して，増 分解析においては, 実験では載荷できなかった大変形領域まで解析 を行い，1 層の柱脚が曲げ降伏して終局状態に達したことを確認し ている.

以上より，弾塑性増分解析によって実験結果を追跡できていると ともに，図10の崩壊プロセスを解析によって追跡できる.

\section{4. 塑性解析による鉛直終局耐力評価}

\section{1 塑性解析による終局耐力評価の概要}

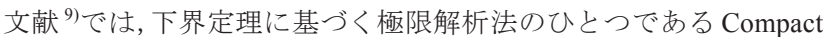
Procedure 法（以下 $\mathrm{CP}$ 法）を用いて崩壊機構を数值演算によって求 め, その結果から崩壊直前の変形を計算し，新たな耐荷機構の発現 を探索する一連の解析法を提案した。 得られた耐荷機構に対して, 上界定理に基づく塑性解析によって, 終局状態における耐力と崩壊 機構が追跡できる可能性について検討した ${ }^{9)}$, 10), 12). 前章のように, 静的弹塑性解析を行えば, 崩壊時の変形々崩壊機構形成後の耐荷機 構を追跡することが可能であるが，文献 ${ }^{9)} の$ 手法は塑性解析法の新 たな可能性を検討したものである.

文献 ${ }^{11)}$ では，多層骨組の鉛直終局耐荷機構について解析的な検討 を行った，同文献によると，梁端塑性ヒンジ形成による塑性崩壊機 構を形成後, 梁軸力によるカテナリー効果によって柱消失層の柱が 水平崩壊し，終局状態に至ることを示した。これは，本稿第 2 章， 第 3 章と同様の結果である.

そこで，文献 ${ }^{9}$ の手法により鉛直荷重を受ける骨組構造物の終局 挙動を追跡してその耐力を評価し, 実験結果ならびに解析結果との 比較，検討を行う。ここでは，終局状態における崩壊モードが柱消 失層の水平崩壊によるものであると仮定し，極限解析によって評価 する.

\section{2 終局状態における崩壊モードと解析モデル}

実験結果ならびに弹塑性増分解析の結果において，柱消失層の水 平崩壊によって終局状態を迎えることを確認した。そこで，梁端の 曲げ降伏による崩壊機構形成後, 図 16 の崩壊モードによる終局状態 を仮定し, 終局耐力を求める. なお, 塑性ヒンジの曲げ耐力 $M_{p c}, M_{p b}$ 
は, 塑性断面係数に材料試験結果の降伏強さを乗じて求める. また, 実験結果ならびに弾塑性増分解析の結果で, 塑性崩壊後に梁軸力が 増加することが確認されたが, 本章の塑性解析においては耐力相関 の影響は考慮しないものとする.

ここで，実験結果ならびに弾塑性増分解析結果において，梁端降 伏による崩壊機構形成時には, 柱の水平変位はほぼ確認されなかっ た. しかし, その後の梁軸力の増加により, 終局状態においては柱 の水平変形が大きくなる様子が確認された。そこで, 梁端降伏によ る崩壊機構形成時の柱の水平変形は無視するが, 図 16 に示すように 終局状態においては柱の応力と変形が図 17 のような状態になるも のと仮定する。また，塑性ヒンジ以外の部材は剛体とし，図 16,17 の機構を仮定することで, 荷重点の鉛直変位を求めることができる。 これにより, 図 16 の塑性解析モデルより, 終局耐力を求めることが 可能となる.

実験結果において, 柱脚部の治具に回転角が生じたため, この結 果に基づき, 前章の弾塑性増分解析では柱脚部に弾性回転バネを設 けた，その結果，実験結果を精度良く追跡できることを確認した。

一方, 本章の塑性解析法について, 崩壊機構形成後の耐荷機構に対 する汎用的な耐力評価法としての有効性や適用性を検討するにあた り，柱脚固定とした場合の終局挙動と耐力に対して検証する. この 場合, 実験結果を参照することができないため, 前章の弾塑性増分 解析法により柱脚固定の場合の結果を求めて, 本章の塑性解析結果

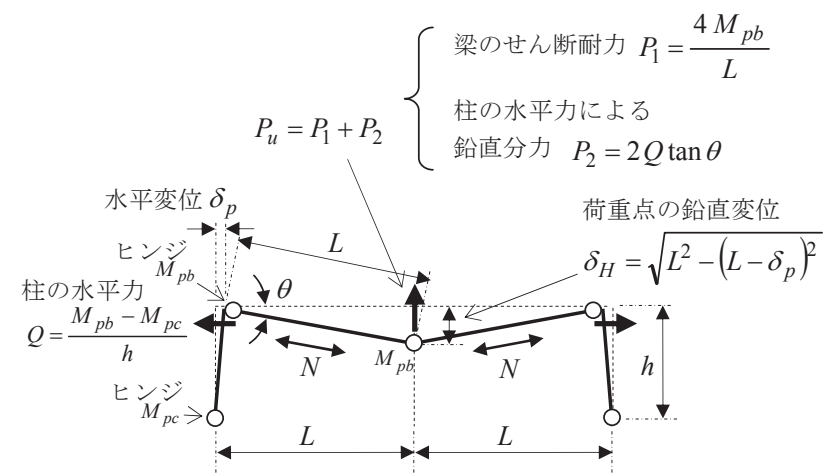

(a) 1 層骨組の場合

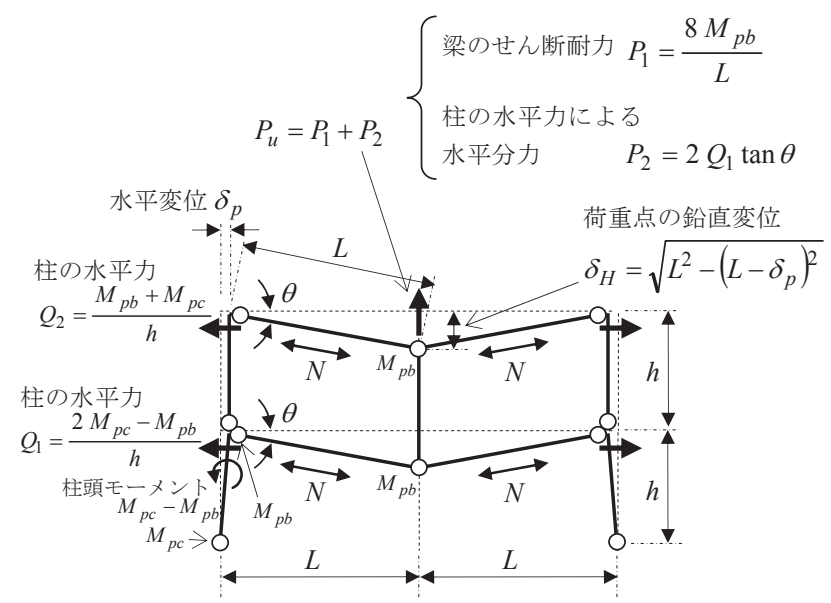

(b) 2 層骨組の場合

図 16 鉛直終局耐荷機構と塑性解析モデル
との比較, 検討を行う.

\section{3 解析結果の比較}

図 16,17 の解析モデルに基づき，1層骨組ならびに 2 層骨組の終 局耐力と, 柱の水平変位 $\delta_{p}$, 梁の部材角 $\delta_{H} / L$ を求め, 柱脚固定と した場合の弾塑性増分解析と塑性解析による解析結果を表 3 に示寸. 表 3 の結果より, 解析結果による終局耐力は, 弾塑性増分解析結 果と比較して 1 層骨組の場合 0.97 倍, 2 層骨組の場合 0.98 倍となっ ている。これより, 図 16,17 の解析モデルによる終局耐力は, 増分 解析の結果を比較的精度良く評価できていることが確認できる。ま た，骨組の変形として，柱の水平変位ならびに梁の部材角について 塑性解析モデルは増分解析の結果を下回っている。 ここで，文献 ${ }^{17)}$ では弾性部材の曲げ剛性や軸剛性は, 弾塑性ジョイントの長さや部 材の反曲点に応じて補正する必要があり, 補正しない場合は曲げ剛 性が小さく評価されることを示している，本章の弾塑性増分解析で は弾性部材の剛性の補正を行っていないため, 増分解析結果におい て柱の水平変位が大きくなったものと考えられる.

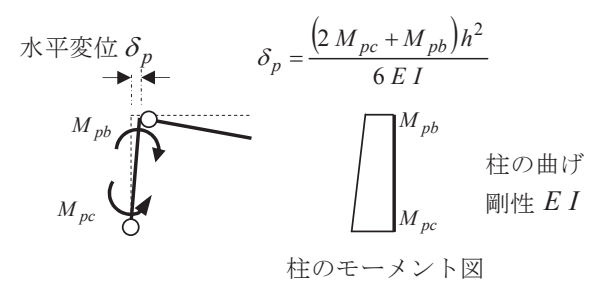

(a) 1 層骨組の場合

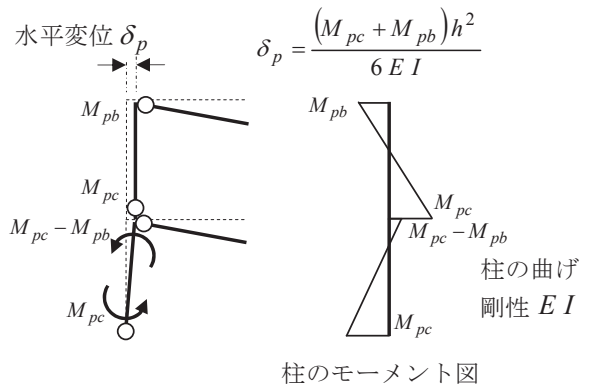

(b) 2 層骨組の場合

図 17 終局状態における柱の応力状態と水平変位

表 3 結果の比較

(a) 1 層骨組の場合

\begin{tabular}{|l|c|c|c|}
\hline & 増分解析 & 塑性解析 & 比較※ \\
\hline 終局耐力 & $14.46 \mathrm{kN}$ & $14.01 \mathrm{kN}$ & 0.97 \\
\hline 柱の水平変位 & $3.79 \mathrm{~mm}$ & $3.44 \mathrm{~mm}$ & 0.91 \\
\hline 梁の部材角 & $0.123 \mathrm{rad}$ & $0.110 \mathrm{rad}$ & 0.89 \\
\hline
\end{tabular}

※比較は, (塑性解析/増分解析) の比率を示寸.

(b) 2 層骨組の場合

\begin{tabular}{|l|c|c|c|}
\hline & 増分解析 & 塑性解析 & 比較※ \\
\hline 終局耐力 & $27.82 \mathrm{kN}$ & $27.30 \mathrm{kN}$ & 0.98 \\
\hline 柱の水平変位 & $2.62 \mathrm{~mm}$ & $1.91 \mathrm{~mm}$ & 0.73 \\
\hline 梁の部材角 & $0.101 \mathrm{rad}$ & $0.080 \mathrm{rad}$ & 0.79 \\
\hline
\end{tabular}

※比較は，（塑性解析／増分解析）の比率を示寸. 
以上より, 部材の面外挙動や座屈, 破断などの不安定挙動が生じ ない場合, 鉛直荷重を受ける骨組が梁端に塑性ヒンジを形成した後, 図 16,17 の解析モデルによって終局挙動ならびに終局耐力を評価す ることができる.

\section{5. 結び}

本研究では，部材消失後の骨組において，鋁直荷重に対する終局 挙動について明らかにするために実験ならびに解析的な検討を行っ た。以下に結論を示す。

1. 1 層 2 スパンならびに 2 層 2 スパンの骨組において, 1 層の中 央柱が消失した後の状態を想定し，試験模型を製作した。

2. 圧縮載荷試験を行い，梁端の塑性ヒンジ形成による崩壊機構 を形成後, 荷重点の変位が進むに従って柱の水平変位, 梁軸 力, 柱脚モーメントの増加により鉛直分力が増加する様子を 確認した.

3.これにより, 鉛直荷重を受ける柱消失後骨組の終局挙動なら びに耐荷機構の推移を実験によって明らかにした，すなわち， 梁端曲げ降伏の崩壊機構形成後に, 荷重点の移動によって梁 軸力が増加し, 当該層の柱の水平力が増加する. 最終的に, 柱脚に塑性ヒンジを形成して当該層の柱が水平崩壊し, 骨組 の終局状態を迎える.

4. 弾塑性増分解析を行い, 実験結果を追跡できることを確認し た. 2 層骨組の実験では, 試験機の変位制御限界に達したため 試験体の終局状態まで載荷できなかったが，増分解析によっ て 1 層骨組と同様, 柱消失層の柱脚が塑性ヒンジを形成して 終局状態に達することを確認した。

5. 上記の耐荷機構の推移により，柱の水平耐力が，梁軸力の増 加を生み, 荷重点の鉛直分力として骨組の鉛直耐力の増加を もたらすことを確認した。

6. さらに, 実験ならびに増分解析の結果を考慮して, 終局状態 における崩壊モードが柱消失層の水平崩壊によるものである と仮定し, 節点移動を考慮した解析モデルに基づき, 終局耐 力を求めた。

7. 結果として, 増分解析結果における終局耐力に対して，1層骨 組では 0.97 倍, 2 層骨組では 0.98 倍の予測精度となっており, 概ね精度良く評価できることを確認した。

\section{謝辞}

本稿の実験は, 平成 22 年度東京理科大学特定研究助成金 (研究代 表者 : 伊藤拓海）より助成をいただきました。また, 実験の実施に あたり, 東京理科大学学部生 井上瑛文君, 木藤陽平君, 森健士郎 君, 元・東京理科大学学部生 涌井将貴君の協力をいただきました. ここに記して謝意を表します.

\section{参考文献}

1) 日本建築学会, 阪神淡路大震災調查報告, 1997.10

2) FEMA-403, World Trade Center Building Performance Study, Data Collection, Preliminary Observations, and Recommendations, 2002.5
3）日本鋼構造協会，崩壊制御設計ガイドライン，2005

4) 伊藤拓海，大井謙一，李正林：鉛直荷重を受ける骨組構造物の冗長性に 関わる感度解析, 日本建築学会構造系論文集, 第 593 号, pp.145-151, 2005.7

5) Frangopol,D.M. et al: Effects of damage and redundancy on structural reliability, Journal of Structural Engineering, ASCE, Vol.113, No.7, pp.1533-1549, 1987.7

6) Feng, Y. S., Moses, F.: Optimum design, redundancy and reliability of structural systems, Computers and Structures, 24, pp.239-251, 1986

7) Schafer, B. W., Bajpai, P.: Stability degradation and redundancy in damaged structures, Engineering Structures, 27, pp.1642-1651, 2005.9

8) Paliou, C. Shinozuka, M., Chen, Y.N.: Reliability and redundancy of offshore structures, Journal of Engineering Mechanics, ASCE, Vol.116, pp.359-378, 1990.2

9) 伊藤拓海：崩壊機構形成後の節点移動による変形を考慮した骨組構造物 の塑性解析法, 第 57 回理論応用力学講演会梗概集, 2008.6

10) 福山達也, 伊藤拓海 : 柔性型骨組構造物の潜在的な構造物耐荷力に関す る研究，その 3 崩壊機構形成後の耐荷機構を考慮した場合の骨組構造物 の而荷力，2009 年度日本建築学会関東支部研究報告集，pp.145-151，2010.2

11）涌井将貴, 福山達也, 伊藤拓海: 柔性型骨組構造物の潜在的な構造物耐 荷力評価法に関する研究，その 5 多層骨組構造物における崩壊機構形成 後の終局挙動，2010 年度日本建築学会関東支部研究報告集，pp.201-204, 2011.2

12) Takumi ITO, Tatsuya FUKUYAMA: A Potential Strength and Ultimate Behavior of Framed Structures Considering Catenary Effects after Failure Mechanism Formation Subjected to Vertical Load, Theoretical and Applied Mechanics Japan, Vol.59, pp.29-38, 2011.2

13) Jinkoo Kim, Dawoon An: Evaluation of progressive collapse potential of steel moment frames considering catenary action, The Structural Design Tall Special Buildings, 18, pp.455-465, 2009

14) 孟令樺, 大井謙一, 高梨晃一: 鉄骨骨組地震応答解析のための耐力劣化 を伴う簡易部材モデル, 日本建築学会構造系論文集, 第 437 号, pp.115-124, 1992.7

15) 陳以一, 大井謙一, 高梨晃一 : 3 方向変動軸力を受ける箱型断面鋼柱の 弾塑性挙動, 日本建築学会構造系論文集, 第 447 号, pp.139-148, 1993.5

16)陳以一: 部材の複合変動応力状態を考慮した鋼構造骨組の弾塑性挙動に 関する研究, 東京大学学位論文, 1993.11

17) 石井正人，斉藤安生，浅野美次，堀井昌博：マルチスプリングモデルの 特性, その 1, その 2, 日本建築学会大会学術講演梗概集, B-1 分冊, pp.383-386, 1997.7

18）大井謙一，李昇宰，西田明美：履歷型ダンパー付鉄骨架構の地震応答性 状，日本建築学会構造系論文集，第 538 号，pp.171-178，2000.12

19）加藤勉，秋山宏 : 鋼構造部材の耐力（その3），日本建築学会論文報告 集，第 151 号, pp.15-20, 1968.9

20）孟令樺，田中清，三山剛史，平澤光春 : 極低降伏点鋼を用いた制震構造 に関する研究-その 4. せん断型制御ダンパーの復元力特性モデル及びそれ を用いた地震応答解析-, 日本建築学会大会学術講演梗概集, B-1 分冊, pp.1045-1046, 1994.9

21）伊藤拓海，大井謙一，嶋脇興介，李王順：履歴型ダンパー付観測用既存 鉄骨造骨組の地震応答実験, 日本建築学会構造系論文集, 第 556 号, pp.161-168, 2003.4

注

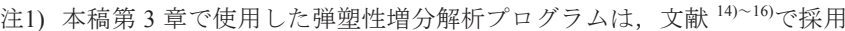
されており，使用方法等については以下に整理されている. 大井謙一, 他 : 鉄骨構造物の弾塑性大変形解析による耐震性向上に関寸 る研究一弾塑性ジョイントモデルによる静的解析プログラム(JULIET) $-, 1992.3$

（2011年 9 月 7 日原稿受理，2011年12月 6 日採用決定） 